\title{
膜応力の平面投影成分を用いた NON-PARAMETRIC SHAPE DESIGN 自由曲面シェルのノンパラメト METHOD OF FREE-FORM SHELLS リック形状設計法 \\ USING MEMBRANE STRESSES PROJECTED ONTO HORIZONTAL PLANE
}

堺 雄亮— $* 1$ 大崎 純— $* 2$

キーワード :

自由曲面シェル, 釣合い形状設計, 平面投影応力, 有限差分法

Keywords:

Free-form shell, Equilibrium shape design, Membrane stress projected onto horizontal plane, Finite-difference method

\section{Yusuke SAKAI_— $* 1 \quad$ Makoto OHSAKI — $* 2$}

A method for shape design of free-form shells under self-weight is presented, without resorting to any parametric shape representations. The graph surface is discretized into a polyhedral surface with quadrilateral mesh. Membrane stresses which satisfy the equilibrium in the horizontal plane are given based on Pucher's formulation, and the equilibrium equation in the vertical direction is solved. Desirable distributions of thrusts on the boundaries of a surface can easily be specified. Successive over-relaxation method is used for solving Pucher's formulation discretized by the finite-difference method. It is shown in the numerical examples that various equilibrium shapes can be generated.

\section{1. はじめに}

球形や円筒形とは異なる複雑な形状を有するシェル構造を自由曲 面シェル構造 1) といい, その形状表現には NURBS (Non-Uniform Rational B-Spline)曲面などのパラメトリックな定義を用いることが 多い 2)。しかし，パラメトリックな表現を用いると，形状がモデル の範囲に限定される。また, 薄肉シェル構造では, 自重に対して膜 応力（面内応力）のみで釣り合うことができる形状が望ましい。そ のような形状は, ひずみエネルギーあるいはコンプライアンス（外 力仕事あるいはひずみエネルギーの 2 倍）を最小化することによっ て求められる ${ }^{3,4)}$ これらの研究では, 最適化と解析のいずれにおい ても 3 角形あるいは 4 辺形の有限要素が用いられ, 形状と厚さを同 時に最適化する研究 ${ }^{5}$, 群知能解法を拡張した解探索アルゴリズム

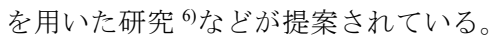

一方，最近になって，graphic statisticsに基づく図式解法を，コン ピュータを用いて実行して釣合い形状を求める方法が研究されてい る $^{7,8)}$ 。組積造などの圧縮の夕で外力に抵抗する材料を用いた連続体 シェルの形状設計においては, Thrust Network Analysis (TNA)によっ て釣合い形状と内力を離散的な双対関係として表現する図式解法が Block et al. ${ }^{9}$ により提案された。また, TNA は, Vouga et al. ${ }^{10}$ により, 設計者の指定した複雑な形状を有する連続体シェルの生成手法一応 用された。さらに，平面グリッドをもとに設計された単純な初期形 状から釣合い形状を生成する最適化手法が提案された ${ }^{11)}$ 。これらの 図式解法を用いると, 高度な構造力学の知識をもたない設計者でも 容易に釣合い曲面を生成することが可能である。形状設計以外にも， TNA は, 組積造の崩壊時に発生するひび割れを予測する解析にも応 用されている ${ }^{12)}$ 。 Miki et al. ${ }^{13)}$ は, 圧縮場と引張場が混在する曲面を 生成した。

水平面座標の関数として高さが与えられる曲面（グラフ曲面）と
して定義される連続体シェルの膜応力の釣合いは，その水平面への

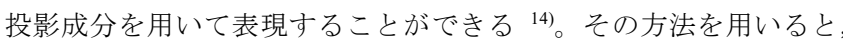
面内力を受ける平板と同様に，面内の釣合いを満たす応力分布を応 力関数を用いて定義できる。水平面内の釣合いが満たされれば，鋁 直方向の釣合い条件から，シェルの形状を求めることができる。Xia et $a l .{ }^{15}$ は, 応力関数と NURBS を用いて自重を受けるシェルの形状 を求める方法を提案した。このように, 応力関数を用いると, 曲面 の設計を応力関数の設計に変換することができる。しかし，上記の 手法では制御点座標に関する曲面高さの高階の微分演算を必要とし, 単純な応力分布の場合を除いて, 微分方程式を解析的に（陽に）解 くことは困難である。Connor et al. ${ }^{16}{ }^{16}$ は，グリッドに離散化されたシ エルの鉛直方向荷重の平面投影成分を指定して，節点の鉛直方向座 標を変数とし，偏微分方程式で記述される釣合い式を有限差分法で 解く手法を提案した。しかし，その手法はせん断応力のない単純な 応力分布を想定し，自由曲面シェルの設計を目的としていない。

シェル構造を設計する際には，境界における水平方向反力（スラ スト）に抵抗するための支持構造物が必要である。水平方向反力は シェル構造と支持構造の両方の剛性に依存するため，一般にはそれ らの構造を同時に設計する必要がある。しかし，反力の分布を指定 することができれば，シェル構造と支持構造を個別に設計すること が可能となる。

本研究では, 文献 16 の手法を拡張して, 自重に対する膜応力の平 面投影成分と水平方向反力分布を指定して，シェルの形状（鉛直方 向座標）を求めるための反復解法を用いた手法を提案する。また， せん断応力を含む種々の応力分布を与えることにより，自重に対し て面内応力で釣り合うことのできるさまざまな形状のシェル構造を, ハンパラメトリックな形状表現によって得られることを示す。
京都大学大学院工学研究科建築学専攻 大学院生・修士（工学）
$($ 干 $615-8540$ 京都市西京区京都大学桂 $)$

京都大学大学院工学研究科建築学専攻 教授・博士 (工学)
Graduate Student, Dept. of Archi. and Architectural Eng., Kyoto Univ., M. Eng.

*2 Prof., Dept. of Archi. and Architectural Eng., Kyoto Univ., Dr. Eng. 


\section{2. 鉛直方向の釣合い式の差分化}

$x y z$ 座標系において, $x, y$ 方向を水平方向, $z$ 方向を鉛直方向と定 め, $z$ 座標が $x, y$ 座標の関数 $h(x, y)$ で表される曲面（グラフ曲面） を考える。このような形状表現は, Monge's description ともいわれる 17- 19)。

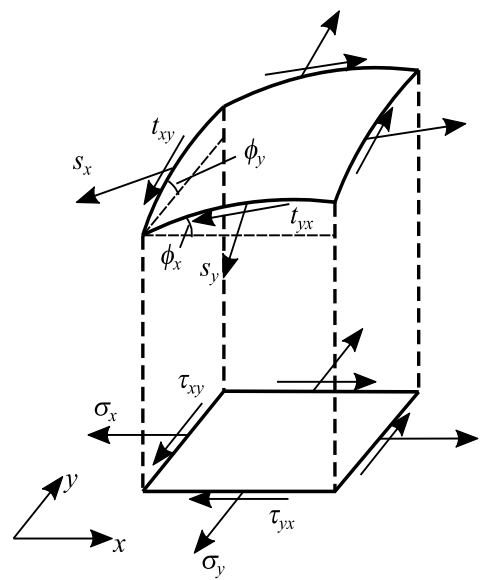

図 1 微小要素に作用するカ

自重に対して膜応力のみで抵抗できるシェルの形状を求めるため, シェルの膜理論を用い, 面外方向の曲げモーメントとせん断力は考 慮しない。以下では, Pucher’s formulationに基づき, シェルの直応 力, 面内せん断応力と外力の釣合いを, それらの $x y$ 平面への投影成 分を用いて表す方法の概要を示す。詳細は文献 14 などを参照された い。

$x y$ 平面に投影した形状が，長方形になるような微小要素を考える。 シェル断面の単位長さあたりの断面力 $s_{x}, s_{y}, t_{x y}, t_{y x}$ を図 1 のように定 義する。ここで，簡単のため断面に分布する力を 1 つの矢印で表し ている。

$s_{x}, s_{y}, t_{x y}, t_{y x}$ を $x y$ 平面に投影し，水平面単位長さあたりの量に換算 した断面力（以下では平面投影応力とよぶ）をそれぞれ $\sigma_{x}, \sigma_{y}, \tau_{x y}, \tau_{y x}$ とする。シェル曲面において $x$ および $y$ 座標がそれぞれ一定の曲線 と $x y$ 平面のなす角度を $\phi_{x}, \phi_{y}$ とすると, 曲面要素の各辺の長さおよ び $x y$ 平面との角度を考慮して, 次の各式を得る。

$$
\sigma_{x}=s_{x} \frac{\cos \phi_{x}}{\cos \phi_{y}}, \quad \sigma_{y}=s_{y} \frac{\cos \phi_{y}}{\cos \phi_{x}}, \quad \tau_{x y}=t_{x y}, \quad \tau_{y x}=t_{y x}
$$

また, $h$ と $\phi_{x}, \phi_{y}$ の間に次式が成立する。

$$
\frac{\partial h}{\partial x}=\tan \phi_{x}, \quad \frac{\partial h}{\partial y}=\tan \phi_{y}
$$

式 (1), (2)および $\tau_{x y}=\tau_{y x}$ を用いると, 微小要素の釣合い式は以下 のように書ける。

$$
\begin{gathered}
\frac{\partial \sigma_{x}}{\partial x}+\frac{\partial \tau_{x y}}{\partial y}=0, \quad \frac{\partial \tau_{x y}}{\partial x}+\frac{\partial \sigma_{y}}{\partial y}=0 \\
\sigma_{x} \frac{\partial^{2} h}{\partial x^{2}}+2 \tau_{x y} \frac{\partial^{2} h}{\partial x \partial y}+\sigma_{y} \frac{\partial^{2} h}{\partial y^{2}}=f
\end{gathered}
$$

ここで, 式(3)は水平方向（ $x, y$ 方向）の釣合い式であり, 水平方向 には外力が作用しないものとする。式(4)は鉛直方向（z 方向）の釣 合い式であり, $f$ はシェルの $x y$ 平面への単位投影面あたりの $z$ 方向 の分布荷重である。板厚が一様なシェルに自重が作用する場合， $f$ は以下のように与えられる。

$$
f=-\rho g d \sqrt{1+\left(\frac{\partial h}{\partial x}\right)^{2}+\left(\frac{\partial h}{\partial y}\right)^{2}}
$$

ここで, $\rho, g, d$ はそれぞれ, 材料密度, 重力加速度およびシェル厚 である。

式(3)を満たす平面投影応力 $\sigma_{x}, \sigma_{y}, \tau_{x y}$ をパラメータとして設定し, 変数 $h$ に関する微分方程式(4)を解いて得られる解が曲面の釣合い形 状である。応力関数を用いた形状設計法の多くの論文では, 圧縮力 あるいは引張力のみで自重に抵抗する形状を求めるため, 平面投影 応力 $\sigma_{x}, \sigma_{y}, \tau_{x y}$ には一定值を与えることが多い。しかし， $\sigma_{x}$ が $y$ の任 意の関数, $\sigma_{y}$ が $x$ の任意の関数であり, $\tau_{x y}$ が定数のとき, 式(3)は満 たされることが分かる。また，境界が $x, y$ 軸に平行であるとき，そ れらに垂直な水平方向反力（単位長さあたり）は，それぞれ $\sigma_{y}, \sigma_{x}$ に一致する。

式(4)は 2 変数の非線形偏微分方程式であり, 特別な応力分布およ び境界条件の場合を除いて解析的に解くことは困難である。したが って, 連続な投影平面を $N \times N$ 分割された正方形の格子に離散化し， 全ての内部格子点において式(4)を差分化する。格子点を $(i, j), i=$ $1, \ldots, N+1, j=1, \ldots, N+1$ とし, 格子点 $(i, j)$ での曲面の $z$ 座標を $h_{i, j}$ とする。 $i, j$ 方向はそれぞれ $x, y$ 方向に対応し, それぞれの格子間隔 を $\delta x, \delta y$ と寸る。変数 $h$ の $x$ に関寸る偏導関数は, 中心差分を用い て次のように計算する。

$$
\begin{gathered}
\frac{\partial h}{\partial x}:=\frac{h_{i+1, j}-h_{i-1, j}}{2 \delta x}, \quad \frac{\partial^{2} h}{\partial x^{2}}:=\frac{h_{i+1, j}-2 h_{i, j}+h_{i-1, j}}{(\delta x)^{2}}, \\
\frac{\partial h}{\partial y}:=\frac{h_{i, j+1}-h_{i, j-1}}{2 \delta y}, \quad \frac{\partial^{2} h}{\partial y^{2}}:=\frac{h_{i, j+1}-2 h_{i, j}+h_{i, j-1}}{(\delta y)^{2}}, \\
\frac{\partial^{2} h}{\partial x \partial y}:=\frac{h_{i+1, j+1}-h_{i+1, j-1}-h_{i-1, j+1}+h_{i-1, j-1}}{\delta x \delta y}
\end{gathered}
$$

これらを式(4), (5)に代入して, 鋁直方向釣合い式の離散化された表 現を得る。式(4)は，境界を除く全ての節点について成立しており， 格子点 $(i, j)$ での荷重項 $f=f_{i, j}$ のみが式(5)に示寸ように非線形であり, 他は線形である。式(4)は $h_{i, j}$ に関して解けるので, 陽的な反復解法 で解が得られる。ここでは, Successive Over-Relaxation (SOR)法を適 用し，その過緩和パラメータを $\omega$, ステップ $n$ での格子点 $(i, j)$ の高さ を $h_{i, j}^{n}$ とすると, 解の更新式は,

$$
\begin{aligned}
h_{i, j}^{n+1}: & =(1-\omega) h_{i, j}^{n}+\omega\left[\frac{2 \sigma_{x}}{(\delta x)^{2}}+\frac{2 \sigma_{y}}{(\delta y)^{2}}\right]^{-1}\left[\frac{\sigma_{x}}{(\delta x)^{2}}\left(h_{i+1, j}^{n}+h_{i-1, j}^{n}\right)\right. \\
& +\frac{\sigma_{y}}{(\delta y)^{2}}\left(h_{i, j+1}^{n}+h_{i, j-1}^{n}\right)+\frac{\tau_{x y}}{2 \delta x \delta y}\left(h_{i+1, j+1}^{n}-h_{i+1, j-1}^{n}-h_{i-1, j+1}^{n}\right. \\
& \left.\left.+h_{i-1, j-1}^{n}\right)-f_{i, j}\right]
\end{aligned}
$$

と書ける。また, 各内部格子点での高さの増分 $h_{i, j}^{n+1}-h_{i, j}^{n}$ の絶対值の 総和が微小值 $\&$ 以になるとき, 収束解を得たとして反復計算を終了 し，曲面の釣合い形状を得る。

\section{3. 数值例題}

\section{1 解析の概要}

以下の例題では, 一般性を失わずに $\rho g d=1$ とし, 応力と長さの単 位も省略する。全ての例で生成された曲面の境界は, 固定支持され る。SOR 法による反復解法のパラメータは $\omega=1.85, \varepsilon=10^{-11}$ とする。 
シェルの水平投影面は正方形の領域 $-1 \leq x \leq 1,-1 \leq y \leq 1$ とし, 格子 の分割数は $N=50$ とする。初期解は, $x y$ 平面上の格子とし, 以下の 釣合い形状の図において, コントアは鉛直方向座標（高さ）の分布 を示す。また，全ての例で反復計算の収束条件を満たし，鉛直方向 反力の総和が自重の総和と十分な精度で一致することを確認してい る。

なお，全ての格子点において式(3)，(4)は成立し膜応力の釣合いを 満たすが，隅角部での釣合いは保証されない。したがって，弾性解 析を行うと, 面外の曲げモーメントとせん断力が発生する。しかし, 格子の分割数を十分に大きくすれば，隅角部で曲げ変形が生じる範 囲を小さくすることができる。

\section{2 モデル 1 : 正方形境界}

4 辺を $x y$ 平面上で固定した正方形境界を考える。平面投影直応力 は $\sigma_{x}=\sigma_{y}=-0.5$ とし, せん断応力は $\tau_{x y}=0$ と寸る。これらは, 水平 方向の釣合い式(3)を満たす。釣合い形状を図 2(a)に示す。せん断応 力を 0 としたため, 形状は $x z$ 平面および $y z$ 平面に関して対称であ る。また, $\sigma_{x}=\sigma_{y}$ であるため, 対角方向の 2 つ鉛直平面に関して も対称である。図 2(b), (c)にはそれぞれ, せん断応力は 0 のまま平 面投影直応力を $\sigma_{x}=\sigma_{y}=-0.25$ および $\sigma_{x}=\sigma_{y}=-1$ とした曲面を示す。 これらの例では $\sigma_{x}$ と $\sigma_{y}$ の比率は変化していないため, 与える応力の 大きさが曲面形状に影響することがわかる。

境界形状を変えずに，平面投影直応力を $\sigma_{x}=\sigma_{y}=-1$ とし，せん 断応力を $\tau_{x y}=-1$ としたときの釣合い形状を図 3(a)に示す。平面投影 応力の主方向は, $x, y$ 軸から $45^{\circ}$ の方向（対角方向）であり, シェ ルの形状は対角方向の 2 つ鉛直面に関して対称である。鉛直方向 反力の分布は図 3(b)のようになり，自重が $x=-y$ の方向に流れて, $(x, y)=(-1,1)$ および $(1,-1)$ 付近の境界で支持されていることがわか る。

\section{3 モデル 2: 筒形境界}

筒形境界をもつシェルの形状を生成する。境界は, $x=1, x=-1$ で $h=0$ とし $, y=-1, y=1$ で $h=-\cosh (x)+\cosh (1)$ とする。平面投影 直応力は, $\sigma_{x}=\sigma_{y}=-1$ とし, せん断応力は $\tau_{x y}=0$ とする。

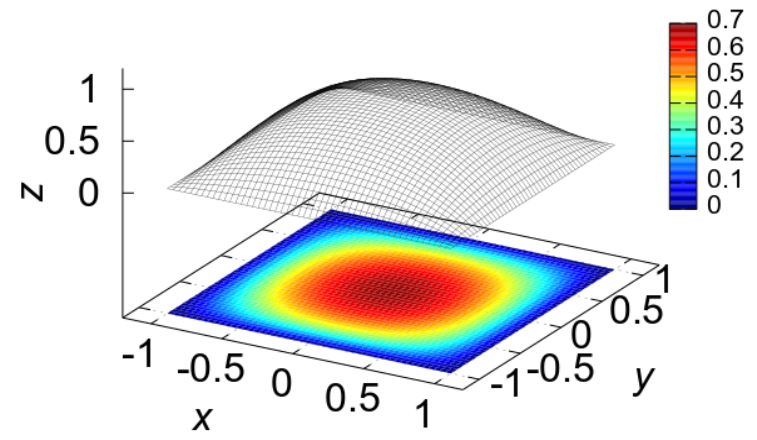

(a) $\sigma_{x}=\sigma_{y}=-0.5, \tau_{x y}=0$

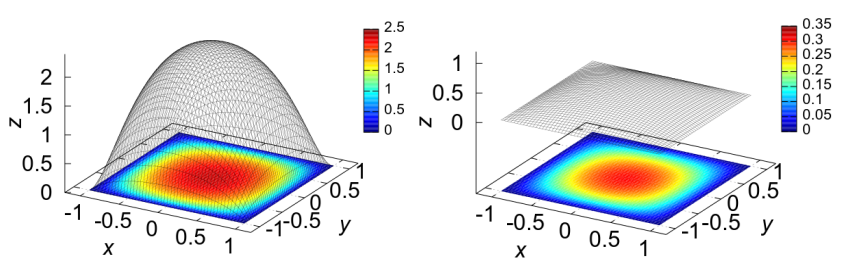

(b) $\sigma_{x}=\sigma_{y}=-0.25, \tau_{x y}=0$

(c) $\sigma_{x}=\sigma_{y}=-1, \tau_{x y}=0$

図 2 モデル 1 の釣合い形状

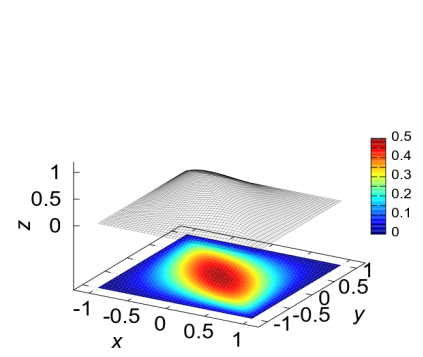

(a) 釣合い形状

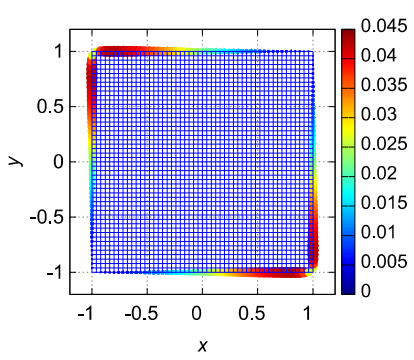

(b) 鉛直方向反力
図 3 モデル 1 の釣合い形状と鉛直方向反カ $\left(\sigma_{x}=\sigma_{y}=-1, \tau_{x y}=1\right)$

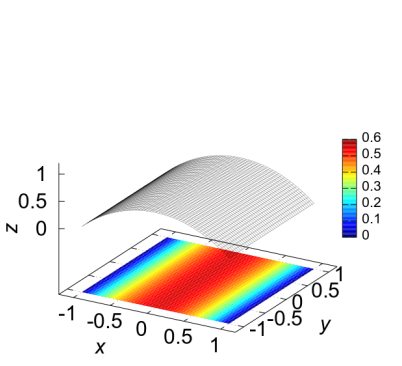

(a) 釣合い形状

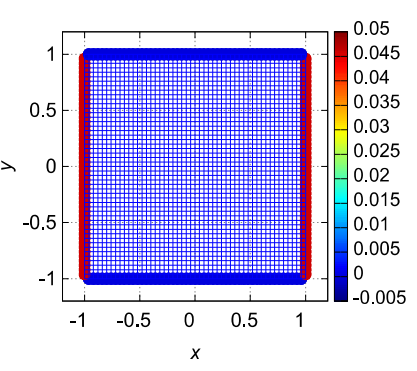

(b) 鉛直方向反力
図 4 モデル 2 の釣合い形状と鉛直方向反カ $\left(\sigma_{x}=\sigma_{y}=-1, \tau_{x y}=0\right)$

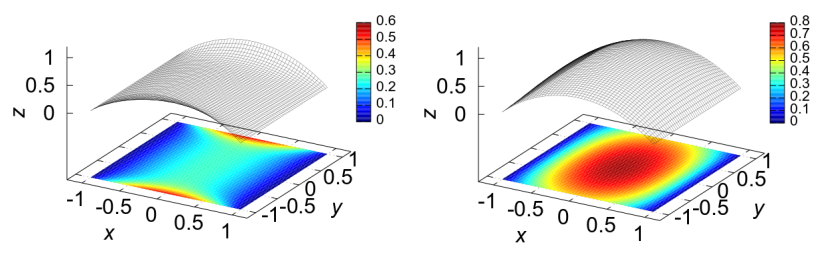

(a) $\sigma_{x}=-2, \sigma_{y}=-0.05$

(b) $\sigma_{x}=-0.5, \sigma_{y}=-1$

図 5 モデル 2 の釣合い形状 $\left(\sigma_{x} \neq-1, \tau_{x y}=0\right)$

境界で指定した形状 $h=-\cosh (x)+\cosh (1)$ はカテナリーであり, 自重 $\rho g d=1$ と $x$ 方向直応力 $\sigma_{x}=-1$ とで鉛直方向の釣合い式を満た すことができる。したがって, $y$ 方向直応力の $z$ 方向成分は不要て あり，図 4(a)のような筒形の釣合い形状が得られる。すなわち，図 4(a)の形状は $\sigma_{y}$ には依存しない。したがって， $x= \pm 1$ の境界での $y$ 方向反力は任意に指定することができる。また, $h$ の $y$ 方向の微分 係数が 0 であるため, 鉛直方向の釣合いは $\tau_{x y}$ に依存せず, $\tau_{x y}$ も任 意に与えることができる。図 4(b)に，鉛直方向反力の分布を示す。 曲面形状は， $x$ 方向のカテナリーアーチを $y$ 方向に推動させた形状 であるため, 自重は $x$ 方向に流れて,$x= \pm 1$ の境界で一様に支持さ れている。

境界形状を変えずに, $\sigma_{x}=-2, \sigma_{y}=-0.05, \tau_{x y}=0$ とすると, $\sigma_{x}$ のみ で自重と釣合うことができないので, 図 5(a)のように $y$ 軸方向に曲 率を有する形状が得られる。さらに， $\sigma_{x}=-0.5, \sigma_{y}=-1, \tau_{x y}=0$ とす ると, 釣合い形状は図 5(b)のようになる。筒形の境界を $h=-\cosh (x)$ $+\cosh (1)$ で与えたとき, $\left(\sigma_{x}+1\right) \sigma_{y}$ が正のとき曲面は下に凸, 負の とき上に凸となる。

\section{4 モデル 3 : 内部境界}

内部に 3 つの正方形の境界を持つ場合を考える。それぞれの境界 において $x$ 座標の範囲と $y$ 座標の範囲は同じであり, それらは $3 つ$ の境界において $[-0.80,-0.48],[-0.20,0.20],[0.48,0.80]$ である。外部 境界の形状は, $x=-1, y=-1$ で $h=0, x=1$ で $h=-\cosh (y)+\cosh (1), y$ $=1$ で $h=-\cosh (x)+\cosh (1)$ である。平面投影応力を $\sigma_{x}=-y-1, \sigma_{y}=$ 


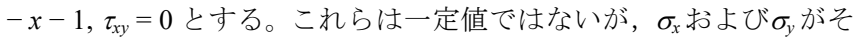
れぞれ $x$ および $y$ に依存しないので, 水平方向の釣合い式を満たす。

$x y$ 平面一の投影面と釣合い形状をそれぞれ図 6(a), (b)に示す。ま た，外部境界上の $x$ 方向および $y$ 方向の単位長さあたりの反力 $H_{x}$ および $H_{y}$ の分布を図 6(c), (d)に, 内部境界上の $H_{x}$ および $H_{y}$ の分布 を図 6(e), (f)に示す。この例でも反復解法による計算は良好な精度で 収束しており, 本手法は内部境界を持ち一様でない平面投影応力 (水 平方向反力）を与えた場合にも有効であることが確認できた。

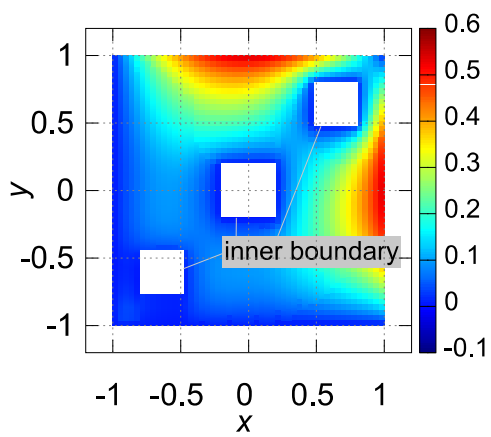

(a) $x y$ 平面投影図

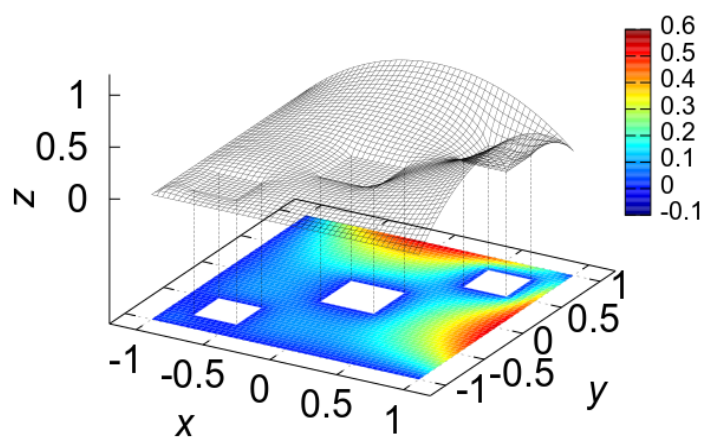

(b) 釣合い形状
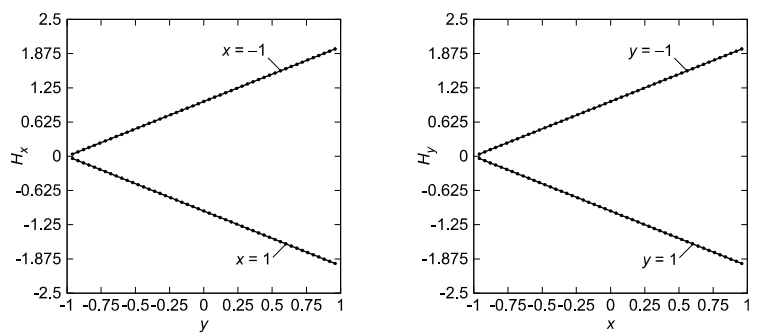

(c)

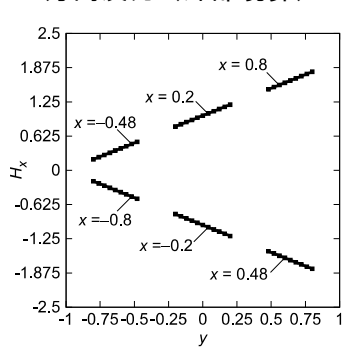

(e) $x$ 方向反力 (内部境界)

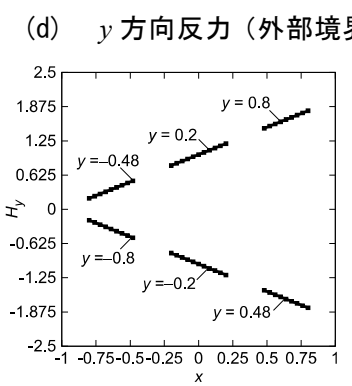

(f) $y$ 方向反力（内部境界）

図 6 モデル 3 の $x y$ 平面投影図, 釣合い形状, 水平方向反力

\section{5 モデル $4:$ HP 形境界}

Hyperbolic Paraboloid (HP)形状の境界をもつ場合を考える。境界形 状は, $x=-1$ で $h=y, x=1$ で $h=-y, y=-1$ で $h=x, y=1$ で $h=-x$ である。平面投影応力を $\sigma_{x}=1, \sigma_{y}=1, \tau_{x y}=0$ としたときの釣合い形
状を図 7 に示す。 $\sigma_{x}$ と $\sigma_{y}$ がともに正（引張）の一定值であり, 自重 が鉛直方向下向きに作用するため, 外力が作用しないとき一様な応 力で釣合うことができる等張力曲面（極小曲面）より，ライズは小 さくなっている。

平面投影応力を $\sigma_{x}=3 y-4, \sigma_{y}=-0.1, \tau_{x y}=0$ としたときの釣合い形 状と水平方向反力の分布を図 8(a)-(c)に示す。この例では， $\sigma_{x}$ と $\sigma_{y}$ がともに負（圧縮）であるため, 中央点のライズが大きくなってい る。

\section{6 モデル 5 : 不連続な平面投影応カ}

$x, y$ 方向平面投影直応力をそれぞれ $y, x$ 方向に不連続に変化させ た場合を考える。これらは応力の作用方向には一定であるため, 水 平面内の釣合いは満たす。式(4)より, 応力の不連続性にともない, 釣合い形状の曲率が不連続になるものと予想される。境界形状は, $x$ $= \pm 1$ および $y= \pm 1$ で $h=0$ である。平面投影応力は, 区間 $-1<y<0$, $0 \leq y<1$ に対してそれぞれ $\sigma_{x}=-0.15, \sigma_{x}=-1$ とし， 区間 $-1<x<0,0$ $\leq x<1$ に対してそれぞれ $\sigma_{y}=-0.15, \sigma_{y}=-1$ とする。また， $\tau_{x y}=0$ と する。

釣合い形状と水平方向反力を, 図 9(a)-(c)に示す。応力および水平 方向反力が不連続であるにも関わらず, 釣合い形状の $x, y$ 方向の勾 配は, 図 9(d), (e)に示寸とおり連続である。一方, 曲率は, 図 9(f)-(h) に示寸とおり, 応力が不連続となっているところで不連続であるこ とを確認できる。

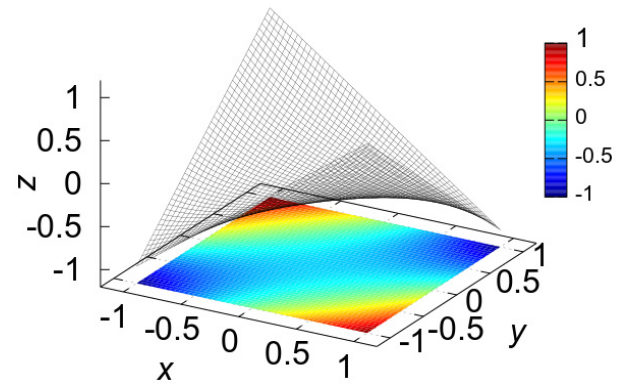

図 7 モデル 4 の釣合い形状 $\left(\sigma_{x}=1, \sigma_{y}=1, \tau_{x y}=0\right)$

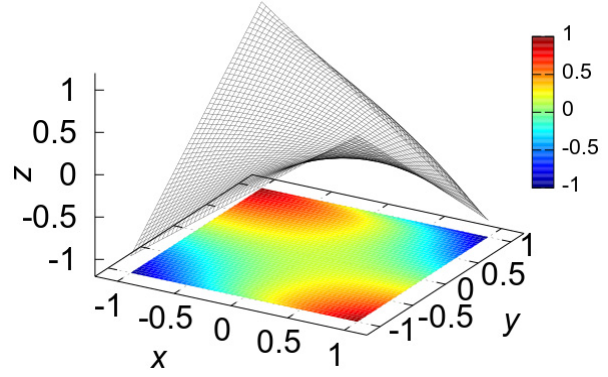

(a) 釣合い形状

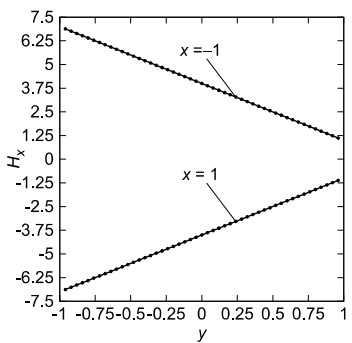

(b) $x$ 方向反力

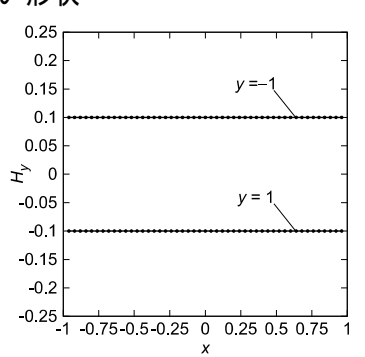

(c) $y$ 方向反力
図 8 モデル 4 の釣合い形状と水平方向反力 $\left(\sigma_{x}=3 y-4, \sigma_{y}=-0.1\right.$, $\left.\tau_{x y}=0\right)$ 


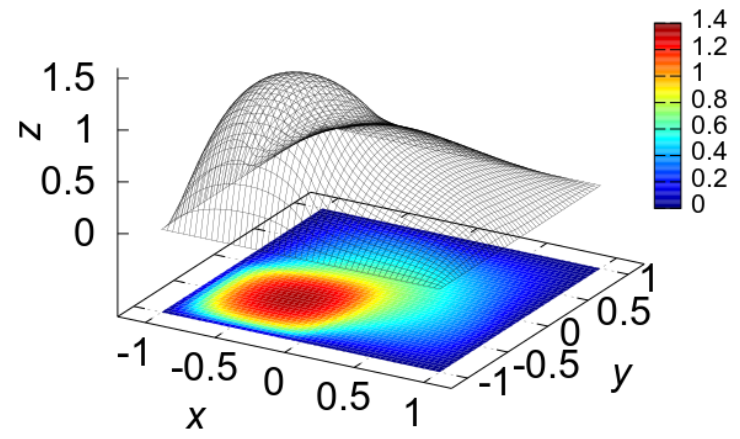

(a) 釣合い形状

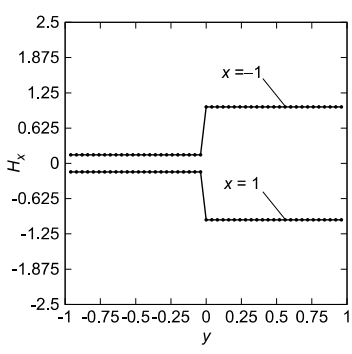

(b) $x$ 方向反力

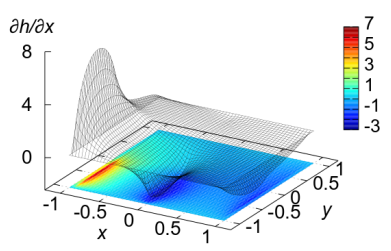

(d) 勾配 $\partial h / \partial x$

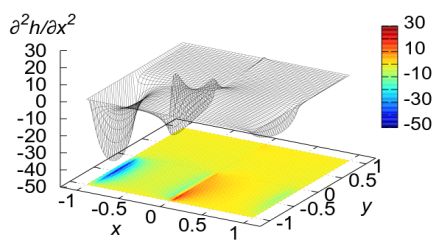

(f) 曲率 $\partial^{2} h / \partial x^{2}$

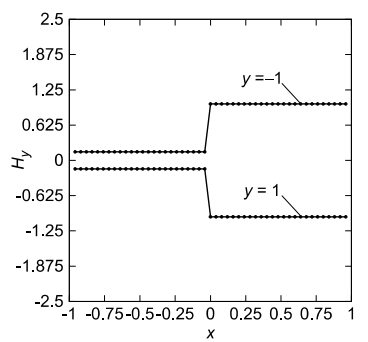

(c) $y$ 方向反力

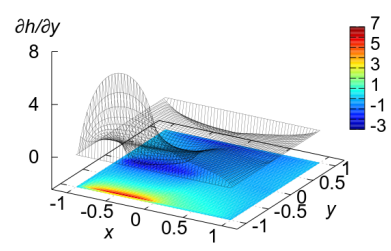

(e) 勾配 $\partial h / \partial y$

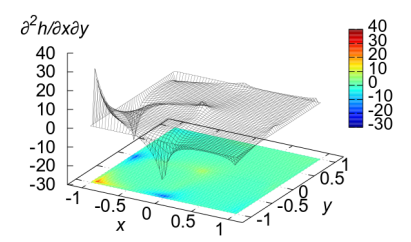

(g) 曲率 $\partial^{2} h / \partial x \partial y$

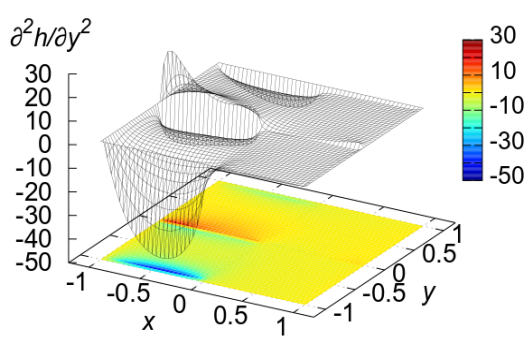

(h) 曲率 $\partial^{2} h / \partial y^{2}$

図 9 モデル 5 の釣合い形状, 水平方向反力, 勾配と曲率

\section{4. 結論}

本研究では, 平面投影応力とノンパラメトリックな形状表現に基 づきシェル曲面形状を生成するための方法を提案した。得られた成 果は以下のとおりである。

1. シェルの平面投影応力を, 水平投影面内の釣合い式を満たすよ うに与えて, 離散化された鉛直方向の釣合い式を反復解法に
よって解くことにより, 自重を受けるシェルが膜応力のみに よって釣合うことができる形状を求めることができる。

2. 一定ではないさまざまな平面投影応力を与えることにより，さ まざまな釣合い形状を生成できる。不連続に分布した応力を 与えた場合, 曲率に不連続性をもつ曲面が得られる。

3. 筒形境界を持つ場合は, カテナリーアーチ形状と, それに釣合 う平面投影応力分布を基準として, 平面投影応力分布を変更 したときの釣合い形状の変化を推定できる。

4. 本手法は, 離散化された曲面の釣合い式を差分演算で解くため, 曲面のパラメトリックな定義は不要であり, 曲面の形状モデ ルに依存しない自由曲面シェルを生成することができる。

5. 平面投影応力を指定することは, 境界でのスラストを指定する ことと等価であり，本手法は，内部境界を持つ場合も含めた さまざまな形状のシェルを設計するために有効な方法である。

\section{謝辞}

本研究は、JST CREST Grant Number JPMJCR1911 の支援を受けた。

\section{参考文献}

1) 坪井義昭, 川口衞, 佐々木睦朗, 大崎 純, 植木隆司, 竹内 徹, 川端昌 也, 川口健一, 金箱温春：力学・素材・構造デザイン, 建築技術, 2012.

2) Farin, G.: Curves and Surfaces for CAGD: A Practical Guide, Morgan Kaufmann, 5th ed., 2001.

3) Bletzinger, K.-U. and Ramm, E.: Form finding of shells by structural optimization, Engineering with Computers, Vol. 9, pp. 27-35, 1993.

4) Fujita, S. and Ohsaki, M.: Shape optimization of shells considering strain energy and algebraic invariants of parametric surface, Journal of Structural and Construction Engineering (Transactions of AIJ), Vol. 74, No. 639, pp. 857-863, 2009. 5 (in Japanese)

藤田慎之輔, 大崎 純：ひずみエネルギーとパラメトリック曲面の代数不 変量を考慮したシェルの形状最適化, 日本建築学会構造系論文集, Vol. 74, No. 639, pp. 841-847, 2009.

5) Kimura, T. and Ohmori, H.: Simultaneous optimization with respect to both shape and thickness and its application, Journal of Structural and Construction Engineering (Transactions of AIJ), Vol. 74, No. 640, pp. 1091-1098, 2009. 6 (in Japanese)

木村俊明, 大森博司：形状と厚さの同時最適化法の定式化とその応用一自 由曲面シェル構造の構造形態創生法の提案（その 1) - , 日本建築学会構 造系論文集, Vol. 74, No. 640, pp. 1091-1098, 2009.

6) Nagata, K. and Honma, T.: Form for free surface shell structure using swarm intelligence with manipulation for decent solution search, Journal of Structural and Construction Engineering (Transactions of AIJ), Vol. 78, No. 684, pp. 345-354, 2013. 2 (in Japanese) 永田洸大, 本間俊雄：優良解探索機能を導入した群知能による自由曲面 シェル構造の形態, 日本建築学会構造系論文集, Vol. 78, No. 684, pp. 345-354, 2013.

7) D'Acunt P., Jasienski J.-P., Ohlbrock P. O., Fivet C., Schwartz J. and Zastani D.: Vector-based 3D graphic statics: A framework for the design of spatial structures based on the relation between form and forces, Int. J. Solids Struct., Vol. 167, pp. 58-70, 2019.

8) Akbarzadeh, M., Van Mele, T. and Block, P.: On the equilibrium of funiculat polyhedral frames and convex polyhedral force diagrams, Computer-Aided Design, Vol. 63, pp. 118-128, 2015.

9) Block, P. and Ochsendorf, J.: Thrust network analysis: a new methodology for three-dimensional equilibrium, Journal of the International Association for Shell and Spatial Structures, 48(3). (2007).

10) Vouga, E., Höbinger, M., Wallner, J. and Pottmann, H.: Design of self-supporting surfaces, ACM Transactions on Graphics, 31. (2012), 87: 1-87: 11. 
11) Panozzo, D., Block, P. and Sorkine-Hornung, O.: Designing unreinforced masonry models, ACM Transactions on Graphics, 32. (2013), $91: 1-91: 11$.

12) Fraternali, F.: A thrust network approach to the equilibrium problem of unreinforced masonry vaults via polyhedral stress functions, Mechanics Research Communications, 37. (2010), 198-204.

13) Miki, M., Igarashi, T. and Block, P.: Parametric self-supporting surfaces via direct computation of Airy stress functions, ACM Transactions, 34(4). (2015), $89: 1-89: 12$.

14) Ohsaki, M, Takeuchi, T. and Yamashita, T.: Basic Theory and Design of Shell and Spatial Structures, Kyoto University Press, 2018.

大崎 純, 竹内 徹, 山下哲郎: シェル・空間構造の基礎理論とデザイン, 京 大出版会, 2019.

15) Xia, Y., Mantzaflaris, A., Juttler, B., Pan, H., Hu, P., and Wang, W.: Design of self-supporting surfaces with isogeometric analysis, Computer Methods in Applied Mechanics and Engineering, 353. (2019), 328-347.

16) Connor, J., J., Lamar, S. and Wolf, J., P.: Automatic solution of Pucher's equation, Journal of the Structural Division, 93(2). (1967), 359-378.

17) Pottmann, H. and Opitz, K.: Curvature analysis and visualization for functions defined on Euclidean spaces or surfaces, Computer Aided Geometric Design, 11. (1993), 655-674.

18) Pottmann, H. and Liu, Y.: Discrete surfaces in isotropic geometry, R.Martin,M. Sabin, J. Winkler (Eds.):Mathematics of Surfaces, LNCS 4647, (2007), 341-363.

19) Gesualdo, A., Cennamo, C., Fortunato, A., Frunzio, G., Monaco, M. and Angelillo, M.: Equilibrium formulation of masonry helical stairs, Meccanica, 52, (2017), 1963-1974.

[2020 年 9 月 25 日原稿受理 2021 年 1 月 5 日採用決定 $]$ 